\title{
RETAIL MARKET STRUCTURE DEVELOPMENT IN CENTRAL EUROPE
}

Machek, M.

This article analyzes the trends and development of the retailing sector in Central Europe, namely in the Czech Republic, Hungary, Poland and Slovakia. These markets serve about 63 million inhabitants. The retail industry in Central Europe has changed dramatically in the last two decades, and has become a model for successful transformation of emerging markets. The retail market is highly concentrated and dominated by Western European retail chains. International retail chains are using all formats of modern distribution. This article is focusing on the development of hypermarkets, supermarkets and discount stores. Due to international retail chains, Central European countries benefit from a dense network of modern shopping places; the intense competition of highly productive retailers contributes to a lower inflation rate because of the so-called Wal-Mart Effect. The constant pressure on prices influences the marketing strategies of both retailers and suppliers.

JEL Classification: L1, L81

\section{Introduction}

The retail industry in Central Europe has changed dramatically over the last two decades, and it has become a model of successful transformation for emerging markets. During the communist regime, state owned companies dominated local markets and consumers had access to a limited offer of goods and services of very low quality. Over the last 20 years, we have observed important changes in many fields. Trends such as internationalization, market concentration, diversification of business formats and usage of new technologies continue to strengthen in Central Europe. In this article, we will analyze all these trends and follow the development of retailing in Czech Republic, Hungary, Poland and Slovakia.

\section{Retail market structure}

Three stages appear to structure the path of change in the retail sector in the region (Dries, Reardon and Swinnen, 2004). The first stage is the pre-transition, or "communist" period (the socialist regime ended in 1989 in all four countries), when the state played a dominant role in the retail sector (in former Czechoslovakia); this was combined in Hungary and Poland with a parallel retail sector that was private, informal, and small-scale. As import of consumer goods from capitalist countries was very limited due to the lack of hard currency as well as for political reasons, the offer of shops was also limited to domestic products of mostly poor quality. In a planned economy, the notion of "the consumer is king" did not exist and consumers suffered from a lack of many products, most goods were not in-stock in shops, opening hours were short, and state shops often had impolite and unmotivated staff. Shopping used to be more of a stress than pleasure for customers.

The second stage is the early transition period of so-called "small privatization" when the transformation started by sales of shops to private owners. Foreign investors encountered obstacles to entering the market due to unclear ownership structures, a ban on participating in privatization auctions, unclear privatization of state enterprises, unstable macroeconomic situations, and in some cases (such as Croatia) civil strife and political instability (Dries, Reardon and Swinnen, 2004). The result of this stage was the existence of fragmented distribution with many domestic undercapitalized small private chains or single shops. Consequently, the shop's offer was much larger as the import of consumer goods rose and local consumers had an extreme consumer appetite.

The third stage is the globalization period. Globalization started in the second half of the 1990s with the massive entry of international retailers. 
Table 1: Key characteristics of the three stages of retail transformation

\begin{tabular}{|l|c|c|c|}
\hline Characteristic & Communism & Transition Stages & Globalization \\
\hline Concentration in the retail sector & High & Low & High \\
\hline Dominant source of capital & Domestic & Domestic & Foreign \\
\hline Foreign investment & - & Brownfield & Greenfield \\
\hline Share of modern retail & Low & Low & High \\
\hline Share of large multinationals & Low & Low & High \\
\hline Location of modern retail outlets & - & Cities & Everywhere \\
\hline
\end{tabular}

Source: Dries, Reador and Swinnen, 2004

The globalization stage is characterized by the opening of the market in Central Europe. This stage offered big retailers a chance to enter an unsaturated market. Central Europe became an opportunity for international retail firms to expand, and especially Western European retail chains were keen to gain as high of shares of the market as possible. American firms, however, have concentrated more on their huge domestic market or other regions and up to now, there are no U.S. firm operating in Central Europe.

\section{Internationalization and Retail Market Concentration}

The internationalization process of the Central European retail market was very fast. Conditions for entering the market in the mid-1990s were favorable - weak local competition without capital resources or business know-how, benevolent legislation and huge consumer appetite. For example, all four countries were listed among the top 30 most attractive emerging markets for international retailers (A.T. Kearney, 1995). Poland was positioned as one of the most interesting markets - it was in $2^{\text {nd }}$ place behind South Korea; Czech Republic was in $10^{\text {th }}$ place, Slovakia $23^{\text {th }}$ place and Hungary in $30^{\text {th }}$ position.

Western European distribution chains understood the market potential and quickly became market leaders. The growth in their own saturated domestic markets was also often limited by legislation (limits of allowed market share, difficulties in obtaining construction permission for new hypermarkets in some countries, etc.) and they started looking for new targets in emerging countries with a favorable geographic situation in the heart of Europe. On the other hand, international competition was tough as many retailers made the decision to enter the market at the same time.

Today, there is strong concentration in the retail market. For example, according to a GfK ConsumerScan, in 2010 the share of the Top 10 in Czech Republic (CZ) was $76.5 \%$, in Hungary (HU) 65.4\%, and in Poland (PL) 57.9\% (Drtina, 2010). The Central European retail market is dominated by
16 international chains, but only two retailers, Tesco and Schwarz Group - with its discount format Lidl - are doing business in all four countries.

Table 2: International retail chains operating in Central Europe (2010)

\begin{tabular}{|l|c|c|c|c|}
\hline Chain (Country) & CZ & HU & PL & SK \\
\hline Lidl (Germany) & $\mathrm{X}$ & $\mathrm{X}$ & $\mathrm{X}$ & $\mathrm{X}$ \\
\hline Tesco (UK) & $\mathrm{X}$ & $\mathrm{X}$ & $\mathrm{X}$ & $\mathrm{X}$ \\
\hline Kaufland (Germany) & $\mathrm{X}$ & - & $\mathrm{X}$ & $\mathrm{X}$ \\
\hline Billa (Germany) & $\mathrm{X}$ & $\mathrm{X}$ & - & $\mathrm{X}$ \\
\hline Penny Market (Germany) & $\mathrm{X}$ & $\mathrm{X}$ & - & $\mathrm{X}$ \\
\hline Spar (Austria) & $\mathrm{X}$ & $\mathrm{X}$ & $\mathrm{X}$ & - \\
\hline Ahold (Netherlands) & $\mathrm{X}$ & - & - & $\mathrm{X}$ \\
\hline Aldi (Germany) & - & $\mathrm{X}$ & $\mathrm{X}$ & - \\
\hline Auchan (France) & - & - & $\mathrm{X}$ & $\mathrm{X}$ \\
\hline Carrefour (France) & - & - & $\mathrm{X}$ & $\mathrm{X}$ \\
\hline Intermarché (France) & - & - & $\mathrm{X}$ & - \\
\hline Cora (France) & - & $\mathrm{X}$ & - & - \\
\hline Globus (Germany) & $\mathrm{X}$ & - & - & - \\
\hline J. Martins (Portugal) & - & - & $\mathrm{X}$ & - \\
\hline Leclerc (France) & - & - & $\mathrm{X}$ & - \\
\hline Reitan (Norway) & - & - & - & $\mathrm{X}$ \\
\hline
\end{tabular}

Source: GfK Austria, author

As for the country of origin with regard to retail chains, the organizations present in the Central European market originate from six different countries. It is not surprising that Germany, because of its geographical and cultural proximity, is an important partner. Five German groups are - with the exception of the family-owned enterprise Globus - doing business in two or more countries. French companies are targeting mainly Poland (4 retail chains) and only Auchan and Carrefour were present in two countries (Poland and Slovakia) in 2010. Other countries are represented by only one chain. 
Figure 1: Grocery Retail Structure in Central Europe in 2011 (\%)

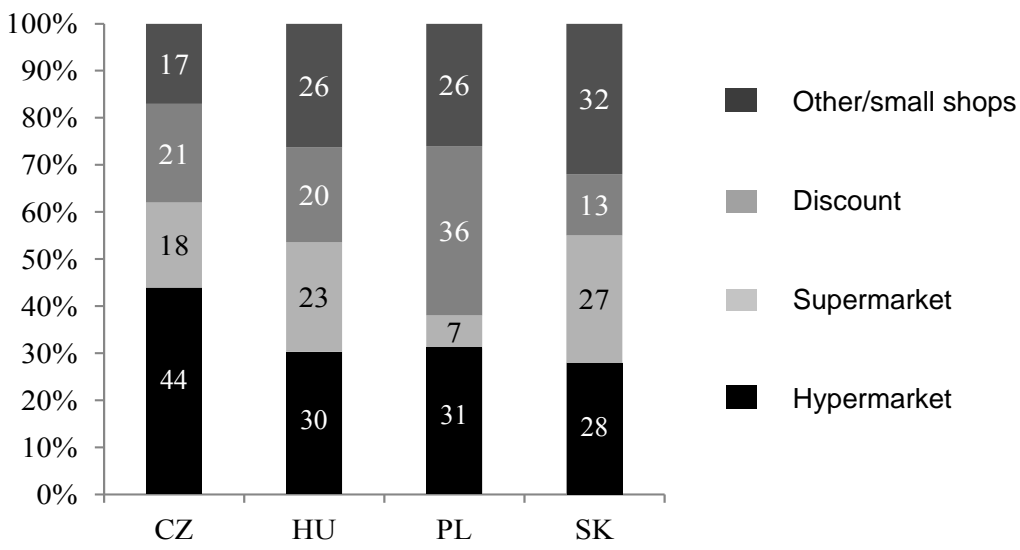

Source: GfK Shopping Monitor CEE 2012

Surprisingly, the biggest player in the biggest market (Poland) is the Portuguese company Jeronimo Martins Group, operating only in one foreign country. This group acquired the Polish company Biedronka in 1997 and it is the only international chain keeping the local brand and using the "local passport strategy". This strategy consists of local positioning and is efficient in countries where consumers tend to prioritize domestic firms over international ones (Machkova, 2009). Biedronka has a $17.5 \%$ market share, more than 1800 stores and $98 \%$ spontaneous recognition, a very successful format.

\section{Expansion of Modern Forms}

The expansion of the modern forms of sales was unprecedented. In the early 1990s, it was normal to go shopping every day and about $80 \%$ of consumers bought fast moving goods in small shops owned by domestic retailers. For example, in 1997, the share of hypermarkets was only $3 \%$ in the Czech Republic and Poland, $2 \%$ in Hungary and there were no hypermarkets operating in Slovakia. In 2011, the ratio was completely reversed in all four countries and the main shopping place became modern format stores, e.g. hypermarkets, supermarkets and discount stores owned by foreign investors.

Nowadays, hypermarkets are the most frequented shopping places in the Czech Republic and Hungary and they are in second place in Poland and Slovakia. In Poland, discount stores have more than $1 / 3$ of the market share and they are in second position in the Czech Republic. The share

\section{Figure 2: Hypermarket expansion in the Czech Republic}

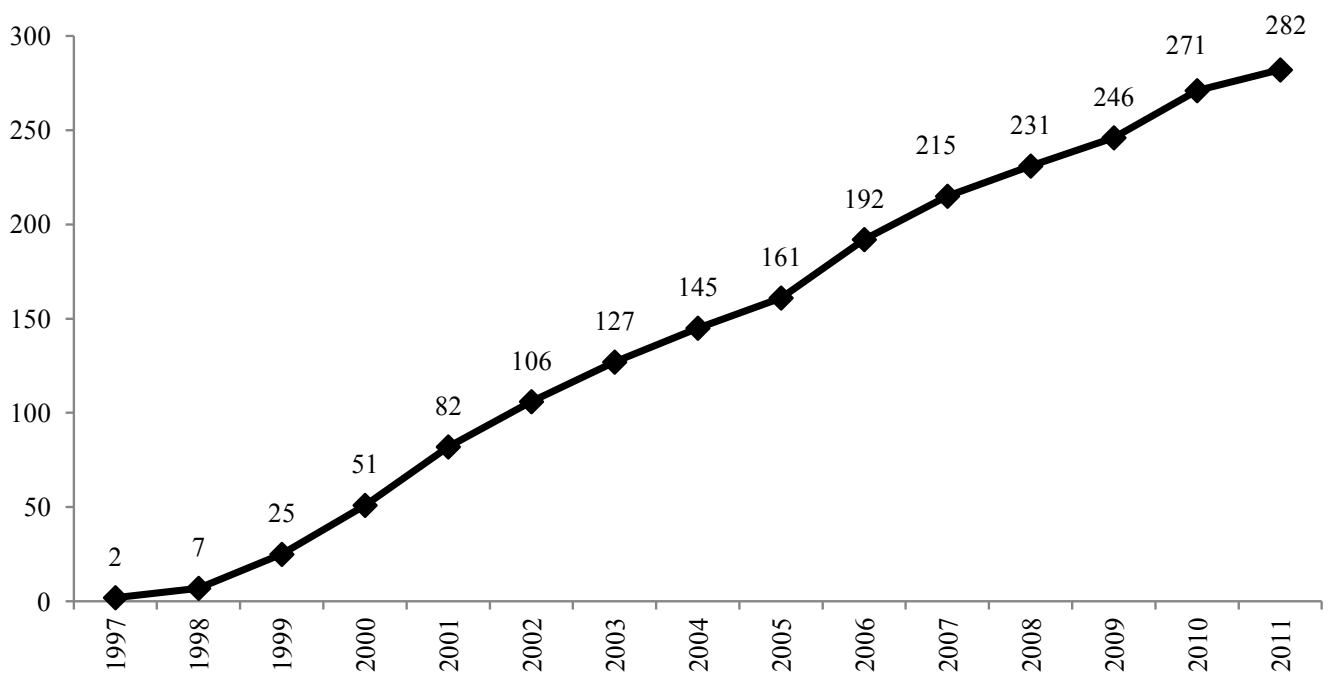

Source: author 
of supermarkets is lower. Hypermarkets are likely to be more important because they have all of the advantages of supermarkets, and most hypermarkets are owned by retail giants that operate internationally, and, hence, have good logistics while some supermarkets operate domestically and are rarely different from small, traditional grocers.

To demonstrate the fast pace of change, we can show the case of the hypermarket growth in the Czech Republic, where the first hypermarkets were opened in 1997 by French Carrefour and German Globus, and 15 years later there were 282 hypermarkets in this small country with 10.3 million inhabitants (see Fig. 2).

The density of hypermarkets (1 hypermarket per some 35000 inhabitants) is higher in the Czech Republic than in most EU countries. Only two EU countries have a higher share of grocery markets than the Czech Republic with $44 \%$, i.e. France (55\%) and UK (51\%). The hypermarket business is run by five international chains: Tesco, Schwarz, Ahold, Spar and Globus (Carrefour did not succeed to acquire sufficient market share and sold-out 11 hypermarkets to Tesco in 2006). The total hypermarket annual turnover was 4.842 billion euros, with the average basket value of 14 euros; the volume of sales per shop was 17.9 million euros in 2010 .

\section{The "Wal-Mart Effect" in Central Europe}

The entry of high-efficiency and low-cost modern retailers was favorable for local consumers as well as for national economies (Machkova, Sterbova 2010). Due to competition, prices remained low and the inflation rate was reasonable (see Table 3).

The term "Wall-Mart Effect" was coined to refer to the downward pressure on prices and is used by Igan and Suzuki to explain the effect of the changing retail industry landscape in Central and Eastern Europe on inflation. The authors found that a 10 percent increase in retail competition reduced the inflation rate for retail traded goods by around 0.5 percentage points. The decline in food inflation associated with retail competition is estimated to be close to 0.6 percentage points, or roughly 30 percent of the average observed inflation rate among the 2005 sample of countries.

With more firms entering into the market, each firm found it more difficult to differentiate its characteristics such as assortment, product and service quality, location of shops, etc. from its competitors. Consequently, firms start bidding harder against each other, ending up with lower market price (A. T. Kearney, 1995).

The pressure on low prices influences the marketing strategy of both retailers and suppliers, especially during the financial crisis. In Poland, Hungary and Slovakia, price sensitivity is so important that for half of households, price has become the first factor in a consumer's choice of where to grocery shop (see Fig. 3).
Table 3: Annual inflation rate (1997-2011)

\begin{tabular}{|l|r|r|r|r|}
\hline Year & CZ & HU & PL & SK \\
\hline $\mathbf{1 9 9 7}$ & 8.0 & 18.5 & 15.0 & 6.0 \\
\hline $\mathbf{1 9 9 8}$ & 9.7 & 14.2 & 11.8 & 6.7 \\
\hline $\mathbf{1 9 9 9}$ & 1.8 & 10.0 & 7.2 & 10.4 \\
\hline $\mathbf{2 0 0 0}$ & 3.9 & 10.0 & 10.1 & 12.2 \\
\hline $\mathbf{2 0 0 1}$ & 4.5 & 9.1 & 5.3 & 7.2 \\
\hline $\mathbf{2 0 0 2}$ & 1.4 & 5.2 & 1.9 & 3.5 \\
\hline $\mathbf{2 0 0 3}$ & -0.1 & 4.7 & 0.7 & 8.4 \\
\hline $\mathbf{2 0 0 4}$ & 2.6 & 6.8 & 3.6 & 7.5 \\
\hline $\mathbf{2 0 0 5}$ & 1.6 & 3.5 & 2.2 & 2.8 \\
\hline $\mathbf{2 0 0 6}$ & 2.1 & 4.0 & 1.3 & 4.3 \\
\hline $\mathbf{2 0 0 7}$ & 3.0 & 7.9 & 2.6 & 1.9 \\
\hline $\mathbf{2 0 0 8}$ & 6.3 & 6.0 & 4.2 & 3.9 \\
\hline $\mathbf{2 0 0 9}$ & 0.6 & 4.0 & 4.0 & 0.9 \\
\hline $\mathbf{2 0 1 0}$ & 1.2 & 4.7 & 2.7 & 0.7 \\
\hline $\mathbf{2 0 1 1}$ & 2.1 & 3.9 & 3.9 & 4.1 \\
\hline
\end{tabular}

Source: Eurostat

The terms "sale" or "price reduction" recently became one of the most frequently used expressions in the Central European retail market. Retailers, together with suppliers, put their money on intensive price marketing (Drtina, 2010). The share of households for which the most important factor of the choice of grocery shop was sale and/or price reduction was $42 \%$ in Slovakia, $41 \%$ in Czech Republic, $36 \%$ in Hungary and $17 \%$ in Poland (GfK Shopping Monitor, 2012).

The phenomenon of ELPD (every-day-low-prices) influenced private label penetration in Central Europe. Compared to Western European countries ( $47 \%$ in UK, $42 \%$ in Germany and 36\% in France for example), this penetration is lower: $29 \%$ in Hungary, $28 \%$ in Slovakia,

Figure 3: Share of households for which the most important factor of grocery shop choice is price (2011)

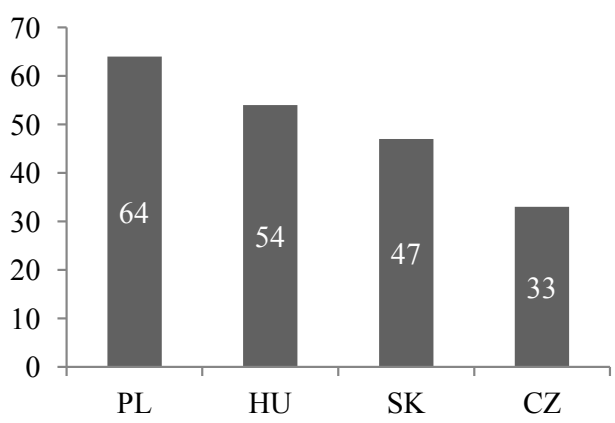

Source: GfK Shopping Monitor 2012 
$25 \%$ in Czech Republic and 24\% in Poland. One of the reasons is that the price policy of producers was influenced by price wars and extreme consumer price sensitivity. For example, since 2009 the value of price reductions was more than $40 \%$ of total sales in the Czech Republic. In such situations, retailers are less motivated to promote their own private labels (Týra and Karlíček, 2012).

\section{Usage of New Technologies - Example of the Czech Republic}

Information technologies are becoming critically important as competitive tools. They are used to produce better forecasts as a tool of marketing intelligence, control inventory costs, support logistics, order electronically from suppliers, support in-store communication with shoppers, improve merchandising-handling systems, etc. The Internet allows promotion of multi-channel retailing, but most retailers have yet to make a bigger Internet push (Machkova and Sterbova, 2010).

As the 2012 research results of a Czech e-commerce agency show, there are more than 21000 e-commerce shops in the Czech Republic and every month hundreds of others appear. This distribution channel represented, in 2011, 1.48 billion euros, meaning a $12 \%$ increase. Consumers' appreciation for time-saving (73\%) and the ability to compare prices $(64 \%)$ are of key importance. E-commerce is mostly concentrated on clothing, electronics and books. Unlike the rest of Europe, Czechs prefer cash on delivery. The boom of e-commerce started with the economic crisis, when consumers started to massively buy through the Internet and also new business entities appeared. Research data indicate that every month there are about 800 new Internet shops, with the mortality rate of about $68 \%$.

As for retail chains, in January 2012, Tesco pioneered on-line shopping in the Czech Republic. What started as a limited possibility for the metropolitan area soon spread to cover $20 \%$ of the population. Data indicate that this activity is very profitable, as the average amount of purchased goods is ten times higher than in regular shopping forms. Within six months, Tesco had 30 thousand registered shoppers who purchased 2.2 million products. This success inspired competitors, and Interspar plans to propose this type of service to consumers as well. We can expect dynamic evolution of Internet shopping.

There are also new, innovative ways, such as virtual drug stores, which have resulted due to the collaboration of Procter\&Gamble and Mall.cz (e-commerce shop). Consumers can purchase household cleaning, laundry and cosmetics/toiletries in the subway stations with their mobile phones. Products are displayed on poles, consumers can take a picture of a special QR code and, through an application, complete the purchase.

\section{Managerial Implications}

The specific conditions after the end of the communist era enabled rapid development of a modern retail industry in Central Europe. Czech Republic, Slovakia, Poland and Hungary represent attractive markets with more than 63 million inhabitants. These new potential markets have become extremely interesting, especially for Western European retail chains. As a result, the competition became very high, leading to a strong concentration, where the most successful chains dominated each market and other retailers left, as was the case of Carrefour in the Czech Republic. We have also observed intensive price wars and what is called the „Wal-Mart Effect" - a lowering effect of price wars on the inflation rate. The entry of high-efficiency and low-cost modern retailers was therefore favorable, not only for local consumers, but also for national economies. As a result of international retail chains, Central European countries can benefit from a dense network of modern shopping places, including all formats of modern distribution. As we have described in this article, the expansion of modern forms of distribution in Central Europe, such as hypermarkets, supermarkets and discount stores, was unprecedented; this was illustrated by the hypermarket evolution in the Czech Republic (282 new hypermarkets in 15 years).

As for the vision for the future of retailing in Central Europe, the most significant factor will be usage of new technologies. Customers are open for Internet purchases and the development of smart phones and QR codes could be fast. Due to competition and a growing standard of living, customers will ask more for quality products and services as well as for the business ethics and corporate social responsibility of retailers.

\section{References}

Alexander, N., Myer, H. (1997). Food Retail Operations in Eastern Europe. European Business Review, 97 (3): 124-33.

A.T. Kerney (1995). Top 30 Most Attractive Emerging Markets for International Retailers..

Bresnahan, T., Reiss, P. (1991). Entry and Competition in Concentrated Markets. Journal of Political Economy, 99 (5): 997-1009.

Delloitte (2009). Global Powers of Retailing 2010. London: Delloite Touche Tohmatsu.

Dries, L., Reardon, T., Swinnen, J. (2004). The Rapid Rise of Supermarkets in Central and Eastern Europe: Implication for the Agrifood Sector and Rural Development. Development Policy Review, 22 (5): 525-556.

Drtina, T. (2010). Crisis influences the shopping behavior of the Czech population and the promotional communication of retail chains, (accessed August 15, 2012), [available at http://www.incoma.cz/en/ols/reader. aspx?msg=1093\&lng=EN\&ctr=203]. 
GfK (2012). Shopping Monitor, 2012. Prague: Incoma GFK.

Author

Igan, D., Suzuki, J. (2012). The Wal-Mart Effect in Central and Eastern Europe, Journal of Comparative Economics, 40 (2): 194-210.

Machkova, H. (2009). Mezinárodní marketing. Prague: Grada.

Machkova, H., Sterbova, L. (2010). The impact of financial crisis on retail industry. In Česká republika a Slovensko v mezinárodním obchodě a podnikáni, ed Cerna, I., Prague: Oeconomica, 2010, 50-56.

Týra, K, Karlíček, M. (2012). Private-Label Share during the Current Economic Slowdown: Investigation from the Czech, Slovak, Hungarian and Polish Markets. Central European Business Review, 1 (1): 27-32.

\author{
Martin Machek \\ Department of Marketing \\ Faculty of Business Administration \\ University of Economics, Prague \\ Winston Churchill Sq. 4, 13067 \\ Prague 3, Czech Republic \\ martin.machek@vse.cz
}

This paper was created with the financial support of the Internal Grant Agency of the University of Economics, Prague, research project IGA2 (VŠE IP300040). 